\title{
Factors predisposing to abnormal pulmonary function after adenovirus type 7 pneumonia
}

\author{
P D SLY, M E SOTO-QUIROS, L I LANDAU, I HUDSON, AND H NEWTON-JOHN \\ Professorial Department of Thoracic Medicine, Royal Children's Hospital, Melbourne, Australia
}

SUMmaRY Adenoviruses are well known causes of respiratory illness in children. Long term sequelae reported with types 3, 7, and 21 include bronchiolitis obliterans, bronchiectasis, and the hyperlucent lung or McLeod syndrome. Twenty children admitted to hospital with adenovirus type 7 pneumonia between 1960 and 1978 were studied and compared with 20 controls admitted during the same period with adenovirus type 7 upper respiratory tract infections. Sixty five per cent of the pneumonia group had developed evidence of airways obstruction compared with $10 \%$ of controls. Young age at the time of pneumonia and a 'measles-like' illness before its onset increase the chance of developing long term pulmonary function abnormalities. Sex and family history of smoking or atopy do not influence outcome.

Adenoviruses are ubiquitous causes of respiratory illness in children. In the western world they have been estimated to cause 1.9 to $2.7 \%$ of acute childhood respiratory illnesses and be responsible for 4.1 to $21 \cdot 8 \%$ of acute respiratory disease requiring hospital admission. ${ }^{1}$ In China up to $59 \%$ of viral pneumonias are due to adenoviruses, predominantly type $7 .^{2}$ The incidence of permanent lung damage after adenoviral pneumonia can be as high as $60 \%{ }^{3}$ Serious long term sequelae reported with types 3,7 , and 21 include bronchiolitis obliterans, bronchiectasis, and the hyperlucent lung or McLeod syndrome. . $^{3-5}$

This study was conducted to document, using detailed pulmonary function tests, the long term pulmonary sequelae of adenovirus type 7 pneumonia and to identify risk factors that increase the likelihood of developing abnormal pulmonary function. A control group who had adenovirus type 7 upper respiratory tract infections was also studied to confirm that long term functional abnormalities were in fact caused by the pneumonia.

\section{Patients and methods}

Virus isolation records at the Fairfield Infectious Diseases Hospital, Melbourne were examined. Twenty patients admitted between 1960 and 1978 with adenovirus type 7 pneumonia could be traced. Pneumonia was diagnosed clinically and supported by chest radiographic changes compatible with adenoviral pneumonia in all cases. Details regarding the admission were collected by retrospective examination of the hospital records.

During the initial illness the specimens for virus isolation were inoculated into tissue culture using HeLa cells, human embryonic cells, and cynomolgus monkey kidney epithelial cells. Cultures were checked for cytopathic effect twice a week. Adenoviruses were typed using neutralisation antibodies.

A control group of 20 patients admitted to the same hospital with adenovirus type 7 upper respiratory tract infection was selected for comparison. All controls had normal chest radiographs. As eight of the pneumonia group had a 'measles-like' illness a further control group of five patients with a diagnosis of measles proved by viral culture during the same period was studied.

Each subject attended the respiratory laboratory at the Royal Children's Hospital, Melbourne, for follow up. Each answered a questionnaire regarding health, clinical examination was performed, and pulmonary function testing carried out. Pulmonary function tests consisted of spirometry, using a Godart 9 litre water filled spirometer according to standardised procedures, ${ }^{6}$ lung volumes in a body plethysmograph, standardised histamine challenge test, ${ }^{7}$ and ear oximetry (Hewlett Packard 47201A). Pulmonary function was regarded as abnormal if testing showed one or more of the following: residual volume/total lung capacity ratio of greater than $35 \%$, forced expiratory volume in one second of less than $80 \%$ predicted, or forced mid-expiratory flow less than $65 \%$ predicted. $^{89}$ 


\section{Statistical analysis}

Statistical analysis was performed by the fitting of a logistic model ${ }^{10}$ to individual data. Logit analysis ${ }^{11}$ allows one to estimate the effects of several risk factors on abnormal lung function and adjust for the possible effects of different sex and age distribution between the risk groups. The data analysis was performed by use of the statistical package GLIM $^{12}$ on the VAX computer system. GLIM provides fitted probabilities of abnormal outcome for each patient based on those factors which significantly influence the probability of a patient developing abnormal lung function.

\section{Results}

The results of the follow up questionnaire did not show any differences between the pneumonia and control groups. No subject in either group reported recurrent respiratory symptoms before the adenoviral infection. Three subjects in each group admitted to smoking and one in each group had been diagnosed as having asthma. Recurrent cough and wheeze were reported at follow up in 13 of the pneumonia group and eight of the control group. Family smoking (59\% and $70 \%$ respectively) and atopy (30\% and $55 \%$ respectively) were similar in both groups. Ten of the 13 symptomatic subjects in the pneumonia group had abnormal pulmonary function and two had positive histamine challenge tests. The one subject in the pneumonia group diagnosed as having asthma had normal pulmonary function.

Sixty five per cent (13 of 20 ) of patients in the pneumonia group had developed abnormal lung function compared with $10 \%$ ( 2 of 20 ) of controls. Ear oximetry was normal (greater than $94 \%$ saturated) in all patients. Bronchial provocation tests with histamine were positive in nine $(45 \%)$ controls and in five $(25 \%)$ of the pneumonia group.

Patients' age at the time of illness had a significant effect on outcome $\left(\chi^{2}=10.00, \mathrm{df}=1, \mathrm{P}<0.005\right)$, with younger patients more likely to develop abnormal lung function. The age at illness for the pneumonia patients (mean (SD), 3.2 (2.3) years) was different from controls (5.7 (3.4) years). After adjusting for the age difference between the two groups, a higher proportion of pneumonia patients developed abnormal lung function than controls $\left(\chi^{2}=8 \cdot 37, \mathrm{df}=1\right.$, $P<0.005$ ). The subject's sex and family history of smoking or of atopy had no effect on the probability of developing abnormal pulmonary function. The fitted probability of developing abnormal pulmonary function for each subject $v$ age (Figure) illustrates the influence of age and adenovirus type 7

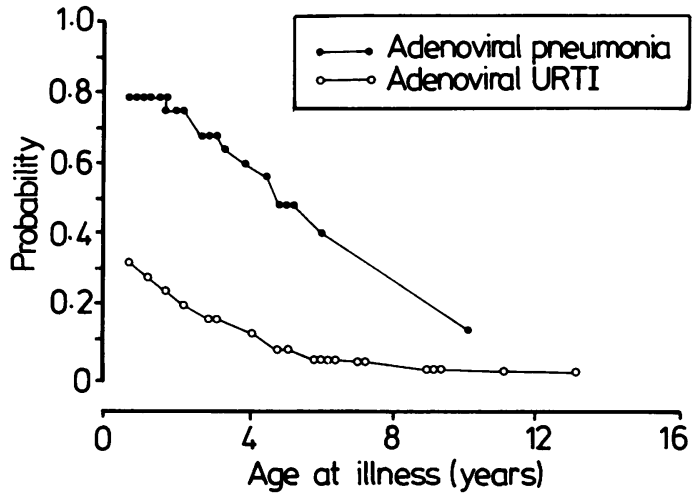

Figure Probability of developing abnormal pulmonary function for patients with adenoviral pneumonia and controls with upper respiratory infections (URTI) against patient's age at the time of illness.

pneumonia on the development of abnormal pulmonary function. Using standardisation techniques ${ }^{13}$ and the fitted probabilities one can obtain predictions of abnormal lung function for cases and controls standardised at the average age of the sample ( 4.5 years). A subject aged 4.5 years with adenovirus type 7 pneumonia is 5.6 times more likely to develop abnormal lung function than a subject of the same age with adenovirus type 7 upper respiration infection.

Eight $(40 \%)$ of the pneumonia group had had a clinical diagnosis of measles made by family medical practitioners within the two weeks before hospital admission. This illness had resolved by the time the children were admitted. The most severe lung function abnormalities were found in this group and none had completely normal pulmonary function tests (Table). To examine the effect of a measleslike illness on the outcome, a logit analysis was performed using the pneumonia cases only. A previous measles-like illness significantly increased the chance of an abnormal outcome $\left(\chi^{2}=9 \cdot 60, \mathrm{df}=1\right.$, $P<0.005)$. Those with a previous measles-like illness were $2 \cdot 4$ times more likely to have abnormal pulmonary function tests. The five subjects with proved measles without subsequent pneumonia who were also studied had normal pulmonary function.

\section{Discussion}

Long term pulmonary sequelae were found in $65 \%$ of those who had had adenovirus type 7 pneumonia - considerably higher than the $20 \%$ incidence in the control group. This establishes that the 
Table Patient details and pulmonary function data

\begin{tabular}{|c|c|c|c|c|c|c|c|c|c|c|}
\hline Group & Patient & $\begin{array}{l}\text { Age at } \\
\text { admission } \\
(y r s)\end{array}$ & $\begin{array}{l}\text { Age at } \\
\text { follow up } \\
\text { (yrs) }\end{array}$ & Sex & $\begin{array}{l}\text { Hospital } \\
\text { stay } \\
\text { (days) }\end{array}$ & $\begin{array}{l}V C \\
(\% \text { Pred })\end{array}$ & $\begin{array}{l}\text { FEV } \\
(\% \text { Pred })\end{array}$ & $\begin{array}{l}F E F_{25-75} \\
(\% \text { Pred })\end{array}$ & $\begin{array}{l}\text { TLC } \\
(\% \text { Pred })\end{array}$ & $\begin{array}{l}R V: T L C \\
(\%)\end{array}$ \\
\hline $\begin{array}{l}\text { Control } \\
\qquad(n=20,12 \text { boys: } 8 \text { girls })\end{array}$ & $\begin{array}{r}1 \\
2 \\
3 \\
4 \\
5 \\
6 \\
6 \\
7 \\
8 \\
9 \\
10 \\
11 \\
12 \\
13 \\
14 \\
15 \\
16 \\
17 \\
18 \\
19 \\
20\end{array}$ & $\begin{array}{l}13 \\
6 \\
9 \\
9 \\
2 \cdot 8 \\
4 \\
3 \\
7 \\
0 \cdot 6 \\
6 \\
11 \\
9 \\
6 \\
6 \\
5 \\
1 \cdot 6 \\
1 \cdot 1 \\
4 \cdot 7 \\
7 \\
2 \cdot 1 \\
5 \cdot 7(3 \cdot 4)\end{array}$ & $\begin{array}{l}16 \cdot 5 \\
11 \\
12 \cdot 5 \\
14 \cdot 5 \\
10 \\
8 \cdot 5 \\
10 \\
11 \\
9 \\
10 \\
16 \\
13 \\
14 \\
13 \cdot 5 \\
18 \\
9 \\
15 \\
19 \\
14 \cdot 5 \\
9 \\
12 \cdot 7 \quad(3 \cdot 2)\end{array}$ & 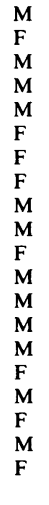 & $\begin{array}{l}5 \\
5 \\
4 \\
7 \\
4 \\
4 \\
6 \\
4 \\
9 \\
3 \\
3 \\
7 \\
3 \\
7 \\
4 \\
4 \\
3 \\
2 \\
4 \\
5 \\
4 \cdot 6(1 \cdot 7)\end{array}$ & $\begin{array}{r}113 \\
86 \\
85 \\
87 \\
95 \\
112 \\
97 \\
80 \\
100 \\
109 \\
124 \\
113 \\
91 \\
89 \\
117 \\
102 \\
99 \\
104 \\
118 \\
105 \\
101(12 \cdot 5)\end{array}$ & $\begin{array}{r}115 \\
96 \\
81 \\
93 \\
98 \\
113 \\
97 \\
82 \\
102 \\
111 \\
121 \\
103 \\
89 \\
92 \\
108 \\
101 \\
84 \\
99 \\
111 \\
101 \\
99 \cdot 9(11 \cdot 0)\end{array}$ & $\begin{array}{r}137 \\
98 \\
70 \\
81 \\
77 \\
98 \\
80 \\
74 \\
103 \\
111 \\
96 \\
81 \\
99 \\
89 \\
80 \\
92 \\
84 \\
79 \\
109 \\
79 \\
91 \cdot 5 \quad(15.9)\end{array}$ & $\begin{array}{l}106 \\
88 \\
75 \\
81 \\
91 \\
114 \\
86 \\
73 \\
104 \\
106 \\
112 \\
104 \\
83 \\
89 \\
118 \\
116 \\
89 \\
98 \\
116 \\
112 \\
98 \cdot 1 \quad(14 \cdot 5)\end{array}$ & $\begin{array}{l}22 \\
32 \\
30 \\
23 \\
25 \\
42 \\
19 \\
24 \\
30 \\
31 \\
30 \\
25 \\
29 \\
34 \\
32 \\
48 \\
23 \\
32 \\
23 \\
31 \\
29 \cdot 3(6 \cdot 9)\end{array}$ \\
\hline $\begin{array}{l}\text { Pneumonia } \\
\text { Without measles-like } \\
\text { illness }(n=12, \\
6 \text { boys: } 6 \text { girls })\end{array}$ & $\begin{array}{r}1 \\
2 \\
3 \\
4 \\
5 \\
6 \\
7 \\
7 \\
8 \\
9 \\
10 \\
11 \\
12\end{array}$ & $\begin{array}{l}4 \cdot 5 \\
1 \cdot 0 \\
3 \cdot 9 \\
5 \cdot 0 \\
5 \cdot 0 \\
3 \cdot 0 \\
2 \cdot 0 \\
3 \cdot 3 \\
10 \\
2 \cdot 9 \\
0 \cdot 9 \\
1 \cdot 2 \\
3 \cdot 6(2 \cdot 5)\end{array}$ & $\begin{array}{l}21 \\
8 \\
21 \\
12 \\
21 \cdot 5 \\
25 \\
17 \\
8 \\
25 \\
12 \cdot 5 \\
8 \\
16 \\
16 \cdot 3(6 \cdot 5)\end{array}$ & $\begin{array}{l}\text { M } \\
\text { F } \\
M \\
\text { F } \\
M \\
\text { F } \\
\text { F } \\
\text { F } \\
M \\
M \\
M \\
\text { F }\end{array}$ & $\begin{array}{l}12 \\
12 \\
12 \\
15 \\
9 \\
15 \\
17 \\
10 \\
9 \\
4 \\
7 \\
22 \\
11 \cdot 8 \quad(4 \cdot 9)\end{array}$ & $\begin{array}{r}123 \\
113 \\
106 \\
81 \\
113 \\
109 \\
108 \\
75 \\
104 \\
91 \\
126 \\
87 \\
103(16 \cdot 2)\end{array}$ & $\begin{array}{l}115 \\
109 \\
99 \\
67 \\
114 \\
104 \\
108 \\
69 \\
96 \\
89 \\
122 \\
97 \\
99 \cdot 1 \quad(17 \cdot 2)\end{array}$ & $\begin{array}{r}112 \\
90 \\
107 \\
36 \\
114 \\
74 \\
100 \\
51 \\
80 \\
80 \\
137 \\
99 \\
90 \cdot 8(28.9)\end{array}$ & $\begin{array}{l}114 \\
120 \\
102 \\
104 \\
104 \\
118 \\
103 \\
100 \\
97 \\
104 \\
134 \\
95 \\
107.9(11.4)\end{array}$ & $\begin{array}{l}26 \\
35 \\
27 \\
51 \\
26 \\
28 \\
26 \\
44 \\
28 \\
40 \\
40 \\
40 \\
34 \cdot 3(8 \cdot 6)\end{array}$ \\
\hline $\begin{array}{l}\text { With measles-like } \\
\text { illness }(n=8, \\
4 \text { boys: } 4 \text { girls })\end{array}$ & $\begin{array}{l}1 \\
2 \\
3 \\
4 \\
5 \\
5 \\
6 \\
7 \\
8\end{array}$ & $\begin{array}{l}0 \cdot 9 \\
1 \cdot 0 \\
5 \cdot 0 \\
1 \cdot 6 \\
2 \cdot 0 \\
1 \cdot 5 \\
6 \cdot 0 \\
2 \cdot 8 \\
2 \cdot 6(1 \cdot 9)\end{array}$ & $\begin{array}{l}14 \\
15 \\
22 \\
9 \cdot 5 \\
16 \cdot 5 \\
11 \\
22 \\
16 \\
15 \cdot 8(4 \cdot 5)\end{array}$ & $\begin{array}{l}\mathbf{M} \\
\mathbf{M} \\
\mathbf{F} \\
\mathbf{F} \\
\mathbf{F} \\
\mathbf{F} \\
\mathbf{M} \\
\mathbf{M}\end{array}$ & $\begin{array}{l}15 \\
31 \\
14 \\
45 \\
60 \\
18 \\
51 \\
28 \\
35 \cdot 3(17 \cdot 2)\end{array}$ & $\begin{array}{l}86 \\
82 \\
94 \\
91 \\
61 \\
86 \\
52 \\
90 \\
80 \cdot 3(15 \cdot 3)\end{array}$ & $\begin{array}{l}74 \\
67 \\
83 \\
61 \\
33 \\
66 \\
27 \\
53 \\
58 \cdot 0(19 \cdot 4)\end{array}$ & $\begin{array}{c}62 \\
47 \\
45 \\
23 \\
10 \\
-\quad \\
9 \\
18 \\
30 \cdot 6(20 \cdot 7)\end{array}$ & $\begin{array}{r}87 \\
84 \\
104 \\
137 \\
110 \\
92 \\
137 \\
108 \\
107 \cdot 4(20 \cdot 6)\end{array}$ & $\begin{array}{l}30 \\
32 \\
36 \\
58 \\
59 \\
14 \\
63 \\
39 \\
41 \cdot 4(17 \cdot 1)\end{array}$ \\
\hline $\begin{array}{l}\text { Total pneumonia } \\
(\mathrm{n}=20 \\
10 \text { boys: } 10 \text { girls })\end{array}$ & & $3 \cdot 2(2 \cdot 3)$ & $16 \cdot 1(5 \cdot 7)$ & & $20 \cdot 1(15 \cdot 5)$ & $93.9(19.2)$ & $82 \cdot 7(27 \cdot 1)$ & $68 \cdot 6(39 \cdot 3)$ & $107 \cdot 7(15 \cdot 2)$ & $37 \cdot 1(12 \cdot 8)$ \\
\hline
\end{tabular}

$\mathrm{VC}=$ vital capacity; $\mathrm{FEV}_{1}=$ forced expiratory volume in $1 \mathrm{sec} ; \mathrm{FEF}_{25-75}=$ forced mid-expiratory flow (between $25 \%$ and $50 \%$ of forced expiratory volume; RV/TLC = residual volume:total lung capacity.

sequelae are due to the pneumonic infection and not related to the presence of the virus in the upper respiratory tract. The factors identified in this study that increase the risk of developing long term pulmonary function abnormalities were young age at the time of pneumonia and a previous measleslike illness. The younger age of the pneumonia group raises the possibility that these subjects may have had pre-existing abnormalities. No subject in either the pneumonia or control groups, however, was reported to have had recurrent respiratory 
more detailed pulmonary function testing, especially measurement of lung volumes, which may contribute to the higher incidence of sequelae documented in this series.

The long term functional effect on the lung after adenovirus type 7 pneumonia detected in this study was airways obstruction. This probably occurs in both large and small airways as expressed by reduced forced expiratory volume in one second and forced mid-expiratory flow and increased residual volume/total lung capacity ratios. Other series have reported bronchiectasis, bronchiolitis obliterans, McLeod syndrome, and increased tendency to wheeze after adenoviral pneumonia. ${ }^{3-514}$ No subject in this study reported productive cough. Thirteen subjects in the pneumonia group reported recurrent cough and wheeze. These symptoms are most likely the result of the pneumonia rather than a pre-existing asthmatic tendency. Ten of this group had abnormal pulmonary function but only two had positive histamine challenges and one further subject had a family history of atopy. Three subjects with abnormal lung function were asymptomatic. Follow up radiographs were not part of this study as they could not be justified, so no comment can be made about the incidence of hyperlucent lung or any other radiographic abnormality in this group.

Lung histology in fatal cases has shown diffuse interstitial pneumonitis, hyperplasia of alveolar lining cells, and necrosis of bronchial epithelium. ${ }^{15} 16$ Damage to airway walls in non-fatal cases would lead to airways obstruction and gas trapping as seen in subjects from the pneumonia group. Not every patient with adenovirus pneumonia develops permanent pulmonary sequelae. Young age at the time of pneumonia was found to increase the chance of developing abnormal pulmonary function. Despite the fact that lung is growing by alveolar multiplication at this stage $^{17}$ permanent damage has occurred. Airway closure occurs more readily in young children ${ }^{17}$ and the added stress of inflammatory changes in and around small airways may impair the ability of the younger child to compensate for the acute histopathological changes and so predispose to the irreversible structural changes which develop.

Even allowing for age, a previous measles-like illness was associated with a worse prognosis in this study. All of the subjects in this group had abnormal pulmonary function at follow up. This group also contained the youngest patients and those with the most severe airways obstruction (Table). The diagnosis of measles in these children was presumptive and it is possible that the rash was due to the adenovirus itself. This is unlikely, however, as the rash had resolved before admission to hospital with the acute pneumonic illness. In previous reports of adenovirus pneumonia ${ }^{5} 14151819$ several patients have had a previous measles-like illness and have been among the most severely affected in those series. Warner ${ }^{19}$ described four cases of adenovirus pneumonia after measles and speculated that much of the respiratory morbidity and mortality subsequent upon measles is due to adenovirus. The measles virus is known to produce temporary abnormalities of chemotaxis and cell mediated immunity. ${ }^{20} \mathrm{~A}$ child who contracted adenovirus infection during this immunocompromised period could be expected to have a more severe illness than one with a 'normal' immune system who contracted the infection.

At variance with previous reports, ${ }^{45}$ bronchial hyperreactivity was not found to be associated with a higher incidence of long term pulmonary sequelae. There were no differences between the pneumonia group and the controls in respect of the current incidence of asthma and symptoms suggestive of atopy or family history of atopy. In previous studies $^{45}$ no control group has been included so valid conclusions are difficult to draw from these reports.

\section{Conclusion}

Adenovirus type 7 pneumonia is associated with important long term pulmonary sequelae. The effects on pulmonary function are due to the pneumonic illness. Factors that should make clinicians aware of the possibility of a worse outcome are the young age of the child and a previous measleslike illness.

\section{References}

1 Van der Veen J. The role of adenoviruses in respiratory disease. Am Rev Respir Dis 1963;88:167-80.

2 Chiu F, Li K, Suo Y, Wang H, Chang H, Shao L. Etiology of virus pneumonia among children in Peking 1973-1975. Chin Med J [Engl] 1977;3:125-30.

${ }^{3}$ Lang WR, Howden CW, Laws J, Burton JF. Bronchopneumonia with serious sequelae in children with evidence of adenovirus type 21 infection. $\mathrm{Br}$ Med J 1969;i:73-9.

${ }^{4}$ Simila S, Lunna O, Lannig P, Hukkinen E, Ala-Hauhala M. Chronic lung damage caused by adenovirus type 7: a ten year follow up study. Chest 1981;80:127-31.

5 Gold R, Wilt JC, Adhikari PK, MacPherson RI. Adenoviral pneumonia and its complications in infancy and childhood. J Can Assoc Radiol 1969;20:218-24.

6 American Thoracic Society-Snowbird Workshop on standardization of spirometry. Am Rev Respir Dis 1979;119:831-8.

7 Chai H, Tan RS, Froehlich LA, et al. Standardization of bronchial inhalation challenge procedures. J Allergy Clin Immunol 1975;56:323-7.

8 Cook CD, Hamann JF. Relation of lung volumes to height in healthy persons between the ages of 5 and 38 years. $J$ Pediatr 1961;59:710-4. 
9 Weng TR, Levison H. Standards of pulmonary function in children. Am Rev Respir Dis 1969;99:879-94.

${ }^{10}$ Cox DR. The analysis of binary data. London: Methuen, 1970.

11 Nelder JA, Wedderburn RWM. Generalized linear models. Journal of the Royal Statistical Society 1972;135:370-84.

12 Baker RJ, Nelder JA. The GLIM system. Release 3. Numerical algorithms group. Oxford: Royal Statistical Society, 1978.

13 Lane PW, Nelder JA. Analysis of covariance and standardization as instances of prediction. Biometrics 1982;38:613-21.

14 Steen-Johnson J, Orstavik I, Attramadal A. Severe illnesses due to adenovirus type 7 in children. Acta Paediatr Scand 1969;58:157-63.

15 Jen $\mathrm{K}$, Tai $\mathrm{Y}$, Lin $\mathrm{Y}$, Wang $\mathrm{H}$. The role of adenovirus in the etiology of infantile pneumonia and pneumonia complicating measles. Chin Med J [Engl] 1962;81:141-7.

${ }^{16}$ Lang WR, Howden CW, Burton JF. Bronchopneumonia with serious sequelae in children with evidence of adenovirus type 21 infection. Br Med J 1969;i:73-9.
${ }^{17}$ Kattan M. Long term sequelae of respiratory illness in infancy and childhood. The chest. Pediatr Clin North Am 1979;26: 525-35.

18 Nahmias AJ, Griffith D, Snitzer J. Fatal pneumonia associated with adenovirus type 7. Am J Dis Child 1967;114:36-41.

19 Warner JO, Marshall WC. Crippling lung disease after measles and adenovirus infection. Br J Dis Chest 1976;70:89-94.

${ }^{20}$ Quie PG. The phagocytic system and associated diseases. In: Vaughan VC, McKay RJ, Behrman RE, eds. Textbook of pediatrics. Philadelphia: WB Saunders, 1979:606-10.

Correspondence to Dr P D Sly, Professorial Department of Thoracic Medicine, Royal Children's Hospital, Melbourne, Australia.

Received 1 July 1984 